\title{
Effectiveness of Customer Retention Strategies: A Case of Commercial Banks, Kenya
}

\author{
Emmah Kemunto Mecha ${ }^{1}$, Ogutu Martin ${ }^{2} \&$ Sixtus Momanyi Ondieki ${ }^{1}$ \\ ${ }^{1}$ College of Human Resource Development, Jomo Kenyatta University of Agriculture and Technology, Kenya \\ 2 Department of Business Administration, The University of Nairobi’s School of Business, Kenya \\ Correspondence: Sixtus Momanyi Ondieki, College of Human Resource Development at Jomo Kenyatta \\ university of Agriculture and Technology, P. O Box 4384-40200 Kisii, Kenya. Tel: 254-724-277-105. E-mail: \\ sixtuso2001@gmail.com
}

Received: July 20, 2015

Accepted: August 24, 2015

Online Published: September 18, 2015

doi:10.5539/ijbm.v10n10p270

URL: http://dx.doi.org/10.5539/ijbm.v10n10p270

\begin{abstract}
Retaining customers is key in giving a competitive edge in the banking industry. Banks must identify factors that they need to improve on so as to increase customer retention. Management takes cognizance of the importance of Customer retention in a competitive market or slow increase of new customers. The Kenyan banking industry has been facing challenges in customer retention in the face of increasing competition. Customers are hopping from one bank to another in the hope of finding the one that fit their needs. The following objectives guided this: to establish the retention strategies adopted by commercial banks in Kenya; and to determine the management perception of the effectiveness of such customer retention strategies. This research employed a descriptive research design. The target population comprised of all 44 commercial banks in Kenya. A total of 44 managers involved in strategy implementation were picked to represent the entire population. The sample size was preferred because it was manageable. A semi-structured questionnaire composed of three sections was used to collect primary data where the respondents were accessed through an interview and drop-and-pick later method. The study used a five-point Likert scale to measure the extent of customer satisfaction on effectiveness. Data was collected and analyzed using SPSS package. The study found that commercial banks applied product innovativeness to a very great extent. Commercial banks applied employee training and customer relationship management. The study established that employee training, product innovativeness were perceived as effective as well. Firms need to analyze their customers before coming up with retention strategies. Banks need to come up with ways of rewarding the sales force for retaining customers. Organizations should endeavor to create value for their customers.
\end{abstract}

Keywords: effectiveness, customer retention, strategy, innovativeness, training

\section{Introduction}

Customer Retention remains the key factor in giving a firm a competitive edge. Banks must identify factors that they can enhance customer retention. Kibera and Waruingi (1998) explain that most organizations have in the face of these challenges adopted various strategies to remain relevant and more so in meeting the customer requirements. A study by Muchira (2005) contends that the expanding business environment has led to increased choice for consumers, lower prices, lower margins, dramatically changing global infrastructures, market economies' expanding that is deregulation and privatization, telecommunications infrastructure, investment from analog to digital. Increased expectation has necessitated strategic changes in the way organizations run their business and relate to their customers, that is the overall internal and external environment (Siboe, 2006)

Banks in Kenya have continued to grow in terms of assets, deposits, profits and product offerings. This has been due to an industry-wide branch network expansion strategy, the automation of a large number of services, and an emphasis on the complex customer needs. This has led to increased competition resulting from increased innovations among the players and new entrants into the market (Price Water Coopers Report, 2008)

The commercial banks in Kenya are now operating in a more competitive business environment than before. The importance of strategic management cannot be overemphasized, because it determines how an organization reacts to competition and other business environmental challenges. The way a commercial bank reacts 
strategically to these challenges determines its survival and prosperity. Pelsmacker et al. (2005) acknowledges the importance of establishing customer loyalty in lieu of getting new customers. In the wake of the changing dynamics in the banking sector, Kenyan commercial banks have an uphill task of retaining key value customers, acquiring new customers, building their confidence and maintaining a robust financial performance. Corporate customers who initially would shy away from switching banks are willing to do so if banks ignore the need to hone their service quality (Farquhar, 2004 and Lam \& Burton, 2006).

\subsection{Problem Statement}

From the introduction above, the management of banks accord significant importance of Customer retention due to saturation of existing market or a sluggish growth of new customers. Competition forces firms to actively target the consumer. In order to stay ahead of competition banks continuously scan the environment aggressively and speed up implementation of its retention strategies (Ennew \& Binks, 1996; Woodruff, 1997). The Kenyan banking industry has been facing challenges in customer retention amidst the increasing number of banks and environmental changes. Customers are hopping from one bank to another in the hope of finding the one that fit their needs. Despite the strategic effort to build and promote good customer relationship, customer retention still remains a vital managerial issue.

Numerous studies have tried to examine the effectiveness of customer retention strategies. Abishua, (2010), Adour (2011), Kipkenda (2011), Kirigo (2010), and Njuguna (2010) recommend that banks should enhance the implementation of the strategies that are most effective like customer service and product differentiation in order to remain competitive. Effectiveness of the implemented customer retention strategies still remains an issue to be tackled. This study seeks to investigate the effectiveness of the customer retention strategies adopted by commercial banks. It is necessary to seek answers to the questions: which retention strategies do commercial banks find effective? What perceptions do bank managers have on effectiveness of such customer retention strategies?

\section{Related Literature Review}

Today's competitive environment seeks to maximize customer retention in order to sustain the company's protective edge against new entrants. Fluss (2010) argues that competitors are always working towards attracting customers from other companies through quality product offerings. In his study. In his study, Fluss noted that annual customer attrition rates range from $7 \%$ in industries that have high exit barriers such as banking and insurance, to almost $40 \%$ in the mobile phone industry. Customers in the mobile telephony keep on switching network providers for better deals.

Various writers analyzed different structures and strategies that enable firms to function successfully in different environments. Burns (2006) studied the effects of a rapidly changing technological developments on the attempts of old established firms to adjust to new environments. Lawrence and Lorsch (2006) emphasized the appropriateness of the structure of the organization in relation to its environment that is the basis of effectiveness. Customer retention impacts directly on customer value in the longrun. Firms exploit this avenue so as to $b$ eprofitble (Gee et al., 2008). Supporting this argument, Lombard (2009) notes that today the need to retain customers is fuelled by the market where customer acquisition is low.

The strategies pursued that help retain customers include loyalty, change of channels of distribution creative filtering of quality customers, rewarding the sales force, paying for continuity, and designing special programs that attract and hold the most valuable customers. It entails providing a differentiated attention (Richheld, 1996). Lions (2010) argued that customer service is one of the surest ways of retaining customers. It means that your customers feel that you understand them and their needs outstanding service is what customers require and if this is offered then the customers feel worth of the relationship .A successful business is defined by the relationship it has with its customers. Relationships with customers should be caring and ongoing. This ensures touch and personal relationship you established when the first contact with the customer will be sustained (Jill \& Lowenstein, 2007).

According to Mermann (2007) when you differentiate your products you make your competitor irrelevant and in so doing you guarantee sales for your business that ensuring your survival. Services can be differentiated through speed, performance, quality, responsiveness and availability. Neil (1998) notes that strong brands have the ability to attract and retain customers. Thus all organizations should endeavor to have strong brands so as to enhance their branding in order to build product recognition and loyalty that further enhances customer value. According to Neil, cross selling means selling more products to customers one has already acquired. In cross selling it means that the organization must view itself as a whole so that it can see all the possible relationships involved. Where this relationships intersect a lot of relevant solutions for the customer can be given and this way a customer who would have otherwise left for competition stay and buys more products. 
According to Payne and Frow (2005), customer relationship management (CRM) is important to commercial banks. It entails acquiring, retaining and maximizing the lifetime value of customers. Customer relationship management enhances the value to the customer. In doing this, they make customers feel appreciated and understood and that their needs are met. A CRM system enable organizations to handle every detail of the customer thus significantly impacting on the quality of customer service.

Relationship marketing has gained popularity with growth of technology. According to Dortyol (2009) and Heiman (2005), retention of customers through varying means and practices ensures repeated transaction from the already existing customers. This is done when the company is able to meet the expectation of the customer's way beyond what the competition offers. Studies done from different fields suggest the following strategies for customer retention. To retain customers entails improving customer service quality and satisfaction (Berry \&Parasuraman, 1991; Zeithaml \& Bitner, 1996).

Studies identify the benefits of customer retention to an organization (Reichheld \& Sasser, 1990). This includes the lack of higher initial introducing and attracting costs of new customer, increased value and number of purchases, the customer's better understanding of the organization, and positive referrals. Apart from the benefits of the longevity of customers, customer retention activities are less costly compared to those of customer acquition. Rust and Zahorik (1993) argue that the financial implications of customer acquisition may be five times as costly as customer retention. Consequently, customers retention becomes a priority. Beckett et al. (2000) draw conclusions as to why consumers appear to remain loyal to the same financial provider, even though in many instances they hold less favorable views toward these service providers. Many consumers appear to perceive little differentiation between financial providers, making any change essentially worthless. Secondly, consumers appear to be motivated by convenience or inertia.

Little empirical research that investigates the constructs of customer retention has been done. Most studies have investigated the precursors to customer retention. Other studies focus on developing measures of customer satisfaction, value and loyalty without specifically looking into other potential meaningful constructs. These form the basis of this study. There have been few, if any, attempts to link them to customer retention.

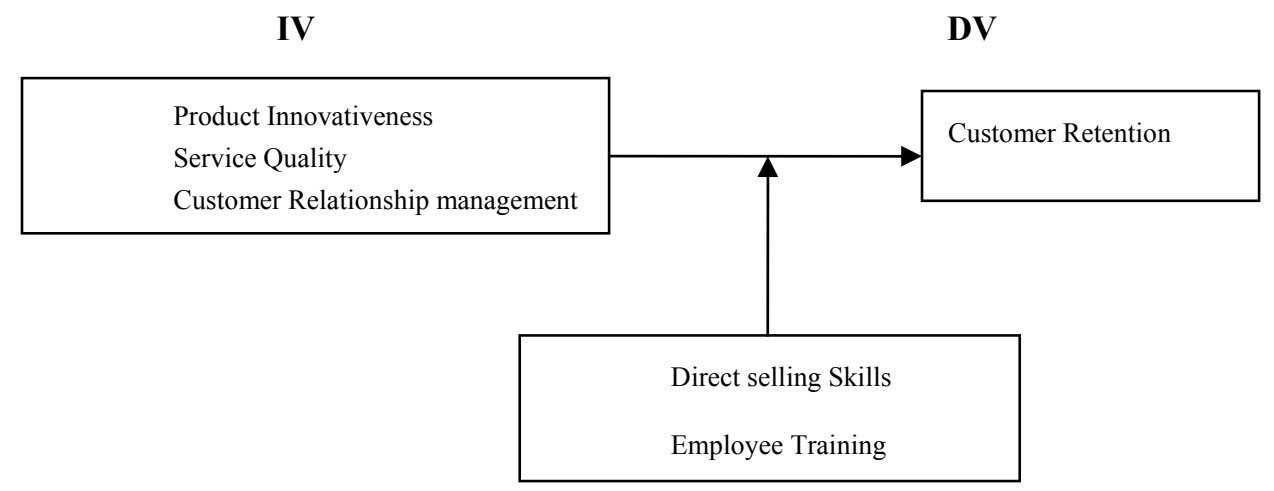

Figure 1. Conceptual framework

\section{Research Methodology}

A descriptive research design was employed. According to Mugenda (1999), this design is best suited where one describes existing phenomena. The population of interest comprised of all commercial banks in Kenya. The respondents were 44 managers from each of the 44 commercial banks. A semi-structured questionnaire was used to collect primary data. The respondents were accessed through an interview and drop-and- pick later method.

Data was collected and analyzed using SPSS package. Descriptive statistics were used to describe and analyze the extent of effectiveness between the various strategies applied.

\section{Findings}

The study sought to find out the extent to which customer retention strategies were effective. The findings were as tabulated below. 


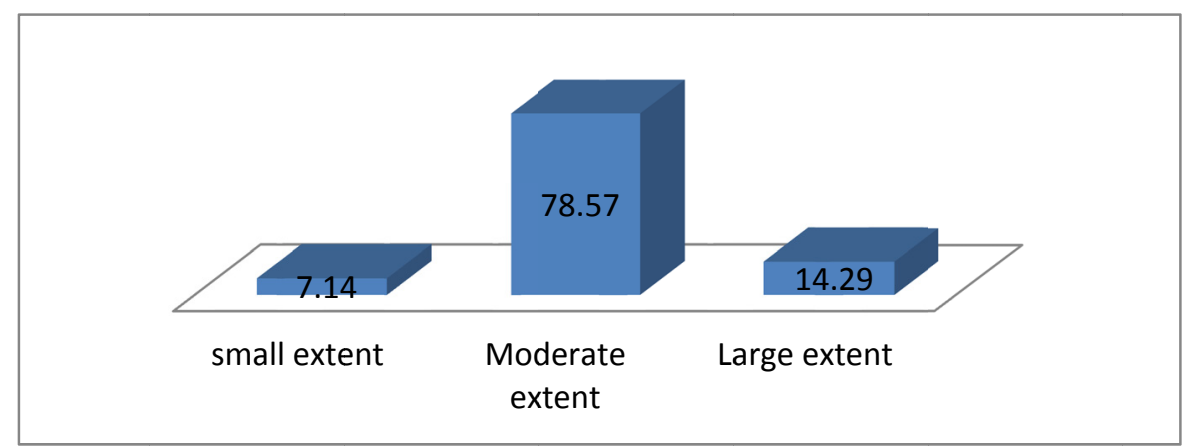

From to the findings above, $78.57 \%$ of the respondents indicated that customer retention strategies were effective to an average extent, $14.29 \%$ indicated that customer retention strategies were effective to a large extent and $7.14 \%$ indicated that customer retention strategies were effective to a small extent. This is an indication that retention strategies as used by banks were averagely effective. This agrees with Adour (2011) who recommends that banks should enhance the implementation of the strategies in order to remain relevant in the competitive market.

The study sought to inquire the effectiveness of customer retention strategies as applied by commercial banks. This section utilized a 5-point likert scale where 1-1.49 = no extent, 1.50-2.49 = low extent, 2.50-3.49= moderate extent, $3.50-4.49=$ great extent, $4.50-5.00=$ very great extent. Commercial banks generally managed a moderate success

The study sought to find out the level of effectiveness of the first objective. Results showed that commercial banks applied product innovativeness to a very great extent giving a mean of 4.67. This implies that customers purchase a variety of added value or benefits. Banks therefore adopt a market orientation approach as explained by Ennew \& Binks (1996) and Woodruff (1997).

The second research objective sought to determine the level of effectiveness of Quality service as a customer retention strategy. Commercial banks applied quality service to a great extent as shown by a mean of 3.79. this tends to agree with Chang, Chan \& Leck (1997) that for banks to gain a sustainable competitive advantage, they need to extend their product quality beyond just the core service.

In measuring the level of effectiveness of customer relationship management as a retention strategy, the study sought to determine the contributions of various tactics for retention. Commercial banks applied loyalty programs, customer involvement and customer satisfaction follow ups to a moderate extent as shown by a mean of 3.48, 3.29 and 2.86 respectively. Moreover, commercial banks applied switching barriers, rewarding loyal customers and lost customer analysis to little extent as shown by a mean of $2.43,1.99$ and 1.86 respectively. Besides, commercial banks did not at all apply discounts on loyalty and complicated products as shown by a mean of 1.46 and 1.45 respectively. The results were as tabulated below. 
Table 1. Customer relationship management tactics

\begin{tabular}{lll}
\hline Strategies & Mean & Std dev \\
\hline Loyalty programs & 3.48 & 0.81 \\
Cross selling & 4.36 & 0.63 \\
Differentiated products & 3.55 & 0.54 \\
Product innovativeness & 4.67 & 0.28 \\
Quality service & 3.79 & 0.49 \\
Employee training & 4.01 & 0.6 \\
Switching barriers & 2.43 & 0.71 \\
Complicated products & 1.45 & 0.62 \\
Long Working hours & 4.45 & 0.67 \\
Discounts on loyalty & 1.46 & 0.53 \\
Customer satisfaction Follow ups & 2.86 & 0.68 \\
Customer Relationship Management & 3.91 & 0.34 \\
Customer Involvement & 3.29 & 0.69 \\
Communication effectiveness & 3.66 & 0.52 \\
Lost customer analysis & 1.86 & 0.51 \\
Rewarding loyal customers & 1.99 & 0.37 \\
Grand Mean & 3.01 & 0.53 \\
\hline
\end{tabular}

According to Payne \& Frow (2005), customer relationship management is important to commercial banks as it helps in customer acquisition and retention so as to maximize their lifetime value. Customer relationship management enhances the value to the customer. Moreover, customer involvement, products differentiation and communication were perceived as effective. According to Dortyol (2009) \& Heiman (2005), a key principle of relationship marketing is the retention of customers through varying means and practices to ensure repeated transaction from the already existing customers.

\section{Recommendations}

The study sought to find out the recommendation to the banking sector for effective strategies. According to the findings, the respondents recommended commercial banks to adopt customer retention strategies and ensure they are effective since they are less costly. This is in agreement with Rust and Zahorik (1993).

Banks need to come up with ways of rewarding the sales force for retaining customers. Commercial banks need to put up a good and quality customer care unit. This will help them deal with customers complains promptly. This need to be advance in that customers are able to contact customer care online or by calling.

Employees should be encouraged to have a good and quality relationship with customers. Customers should be made to feel that bank employees understand them and their needs. Relationships with customers should be caring and ongoing. This ensures that touch and personal relationship are established when the first contact with the customer will be sustained.

\section{References}

Abishua. (2010). Strategic responses used by Equity Bank to compete in the Kenyan Banking industry. MBA Thesis, University of Nairobi. http://dx.doi.org/10.2139/ssrn.1708555

Barney, J., \& Clark, D. (2007). Resource-Based Theory: Creating and Sustaining Competitive Advantage. Oxford: Oxford University Press.

Chen J. I., \& Popovich, K. (2003). Understanding customer relationship management (CRM): People, process and technology.

Colgate, M., Stewart, K., \& Kinsella, R. (1996). Customer Defection: A Study of the Student Market in Ireland. The International Journal of Bank Marketing, 14(3), 23. http://dx.doi.org/10.1108/02652329610113144

David, C., \& Esther, C. (2006). Customer retention in New Zealand Banking industry. Banks and Bank Systems, 1(4).

Don, J., \& Thomas, B. (2012). Assessing customer retention strategies in mobile telecommunications: Hybrid MCDM approach. Management Decision, 50(9), 1570-1595. http://dx.doi.org/10.1108/00251741211266697

Dortyol, K. A. (2009). The difference in customer behaviour between loyal customers and first comers in the 
retail banking industry. Management Research News, 932-941.

Edward, M., \& Sahadev, S. (2011). Role of switching costs in the service quality, perceived value, customer satisfaction and customer retention linkage. Asia Pacific Journal of Marketing and Logistics, 23(3), 327-345. http://dx.doi.org/10.1108/13555851111143240

Gewirtz, M. P. (2005). People power: Strategies for creating work environments to reduce stress and other risks, Thinking out loud.

Hirshleifer, J. (1978). Competition, cooperation, and conflict in economics and biology. American Economic Review, 68(2), 238-243.

Jones A., Mothersbaugh, L., \& Beatty, E. (2003). The effects of locational convenience on customer repurchase intentions across service types. Journal of Services Marketing, 17(7), 701-712. http://dx.doi.org/10.1108/08876040310501250

Kirigo. (2010). Customer retention strategies applied by commercial banks in Kenya. MBA Thesis, University of Nairobi.

Krug, J. A. (Ed.) (2009). SAGE Library in Business \& Management: Corporate strategy. London: SAGE Publications Ltd. http://dx.doi.org/10.4135/9781446261200

Marple, M., \& Zimmerman, M. (1999). A Customer Retention Strategy. Mortgage Banking, 59(11), 45-50.

Matos, C., Henrique, L., \& Rosa, F. (2009). The different roles of switching costs on the satisfaction-loyalty relationship. International Journal of Bank Marketing, 27(7), 506-523. http://dx.doi.org/10.1108/02652320911002331

Menon, K., \& O'Connor, A. (2007). Building customers' affective commitment towards retail banks: The role of CRM in each 'moment of truth'. Journal of Financial Services Marketing, 12(2), 157-168. http://dx.doi.org/10.1057/palgrave.fsm.4760068

Njuguna. (2010). An analysis of effectiveness of customer retention strategies in Equity Bank. MBA Thesis, University of Nairobi.

Reichheld, F. F., \& Sasser, W. E. (1990). Zero Defections: Quality comes to Services. Harvard Business Review, 105-111.

Relationship International Journal of Bank. (2009). The different roles of switching costs on the satisfaction-loyalty (pp. 506-523).

Rizal, F. (2002). Customer retention management;a reflection of theory and practice. Marketing intelligence and Planning, 149-161.

Robert, H. (2005). Retail operations strategies: Empirical evidence of role, competitive contribution and life cycle. International Journal of Operations \& Production Management, 25(7), 642-680. http://dx.doi.org/10.1108/01443570510605081

Storbacka, K., Strandvik, R., \& Gronroos, C. (1994). Managing Customer Relationship for Profit: The Dynamics of Relationship Quality. International Journal of Service Industry Management, 5(5), 21-38. http://dx.doi.org/10.1108/09564239410074358

Wisskirchen, C., Vate, D., Backer, P., \& Detrick, C. (2006). The customer-led bank: Converting customers from defectors into fans. Strategy \& Leadership, 34(2), 10-20. http://dx.doi.org/10.1108/10878570610652590

Wu, L. W. (2011). Beyond satisfaction: The relative importance of locational convenience, interpersonal relationships and commitment across service types. Managing Service Quality, 240-263. http://dx.doi.org/10.1108/09604521111127956

\section{Copyrights}

Copyright for this article is retained by the author(s), with first publication rights granted to the journal.

This is an open-access article distributed under the terms and conditions of the Creative Commons Attribution license (http://creativecommons.org/licenses/by/3.0/). 